\title{
EL PURITANISMO EN LA CONCIENCIA NORTEAMERICANA
}

\section{Presentación}

La preocupación central de mis trabajos ha sido la elaboración de una Historia de las Ideas en América. Por supuesto, así en general, se trataría de un trabajo ambicioso, de casi imposible realización para un hombre. Sin embargo, es una tarea en la cual han venido laborando diversos investigadores, tanto en la América Sajona como en la América Latina. Trabajos aún dispersos; muchos de ellos desconocidos aún por investigadores entregados a la misma tarea. Sin embargo, algo se ha venido ya realizando para unificar estos esfuerzos y estimular otros nuevos. ${ }^{1}$ Partiendo de estos trabajos y realizando investigaciones ahí donde se presenten lagunas, se puede ya intentar un análisis hermenéutico de estas ideas. $Y$ por ideas no se va a entender, en este caso, todas las ideas que pueden hacerse patentes en un estudio sobre América. No, más bien de lo que se trata es de captar ese hilo de sentido que da unidad a toda historia. Hilo de sentido que unifica $y$ da perfiles a lo que parece dispersa, por múltiple, actividad del hombre. Conjunto de sentidos que hace posible hablar del espíritu de un pueblo, a diferencia de otros; de una cultura, en lugar de otras. Esto es, ese sentido que haga posible, no sólo la elaboración de una Historia de las Ideas en América, sino también la de una Filosofía de la Historia Americana.

Desde luego, es mucho lo que podría discutirse sobre la elaboración final de esta Filosofía de la Historia. Mucho sobre la posibilidad de la misma y sobre su valor. Dilthey y Croce, entre otros, han hecho agudas críticas a esta Filosofía; pero también nos han dotado de un extraordinario instrumental para interpretar la Historia, hágase o no Filosofía de la Historia. Lo importante es esta interpretación. Lo importante es buscar el sentido a una serie de hechos concretos para comprenderlos. Toda Historia o Filosofía de la Historia o Interpretación de la Historia es eso, intentos para comprender, desde una personal y concreta situación, a un determinado pasado que, en alguna forma, sigue actuando sobre nuestro presente y limitando muchos de nuestros proyectos en el futuro. Por supuesto, son estos proyectos y este presente los que van determinando la interpretación de nuestro pasado, en función con su potencia actual.

Desde este punto de vista es menester intentar una interpretación de la

1 Trabajo que se viene realizando en toda la América a través del Comité de Historia de las Ideas en América de la Comisión de Historia del Instituto Panamericano de Geografía e Historia. 
Historia de América que vaya apoyándose en una serie de hechos concretos, tanto históricos, como políticos, sociales, económicos o religiosos. Unas veces el factor determinante será el económico, otras el religioso, o el social o el político; sin embargo, en ningún caso, los otros dejarán de actuar, dando así lugar a ese especial perfil que expresará una etapa de esta Historia. En la actualidad las investigaciones publicadas nos pueden dar puntos de partida para estas interpretaciones, aunque nunca podamos considerarlas como definitivas. Después de todo, cada época tiene su propia interpretación de la Historia, de acuerdo con sus intereses presentes y futuros. Pero no es tan propia y personal que no diga nada a los hombres de otras épocas; los cuales, en alguna forma, reciben a su vez el impacto del espíritu que animó a la interpretación.

Estas interpretaciones nos permitirán ir elaborando, como ya se ha dicho, el perfil de esta entidad cultural llamada América. Perfil que en ninguna forma podrá ser considerado como una abstracción, como una expresión cultural desligada de las fuentes donde se ha originado. Todo lo contrario, esta Historia deberá mostrar sus relaciones con la cultura que le es original; mostrar cómo ha sido recibida y asimilada. Una Historia de las Ideas de América deberá mostrar también cómo una serie de ideas originarias de la Cultura Europea han sido interpretadas y utilizadas dentro de la realidad propia del hombre americano. Es esta interpretación, y utilización, la que va perfilando la personalidad que puede ser América como expresión de los múltiples esfuerzos realizados por sus hombres para resolver los problemas que va planteándole su situación o circunstancia.

Esta Historia de las Ideas en América, enfocada de acuerdo con los límites ya indicados, deberá ser hecha por partes. La primera deberá referirse a lo que podemos llamar los Inicios u Orígenes de la Conciencia Americana. Este es el trabajo que me he propuesto realizar como investigador del Centro de Estudios Filosóficos. Esta investigación deberá abarcar la etapa de esa historia que se refiere a las ideas que animaron el Descubrimiento, la Conquista y la Colonización de América; tanto desde el punto de vista iberoamericano o, más ampliamente, latino -para abarcar la parte correspondiente a Francia-, como desde el punto de vista sajón.

Esta investigación deberá igualmente interpretar y comprender el espíritu que animó a los buscadores y descubridores del Nuevo Mundo. La relación de este espíritu con diversas formas de la Cultura Europea de ese tiempo. Los conflictos que se plantearon a estos hombres al surgir, dentro de su propia cultura, diversas y nuevas interpretaciones del Mundo y de la Vida: esas interpretaciones que han dado lugar a la llamada Modernidad en contraposición con la Cristianidad. Centralmente, esta investigación también deberá hacer patente el conflicto que se planteó a estos hombres al encontrarse con América. Conflicto de culturas mediante el cual obtenían, a su vez, elementos para resolver su conflicto interno. Pues el descubrimiento de América permitió al 
europeo entrentarse a sus interno-contradicciones provocadas por la crisis de] Mundo Cristiano, con instrumentos ideológicos abstraídos de su encuentro con el Nuevo Mundo. Pero este encuentro entre el Viejo y el Nuevo Mundo planteó al primero graves problemas. Problemas a los cuales se enfrentaron los europeos desde dos puntos de vista: el cristiano y el moderno. Interpretaciones que son, a su vez, expresión de la pugna ya planteada en el Viejo Continente, que fué traída al Nuevo Mundo por sus descubridores, conquistadores y colonizadores.

Una fué la interpretación que sobre América y sus habitantes ofreció e] hombre europeo aferrado aún a sus viejas creencias cristianas; y otra la interpretación que ofreció el europeo moderno buscando la justificación de sus nuevas ideas e ideales. En ambas el hombre americano y su circunstancia concreta quedaron subordinados a los respectivos intereses del descubridor y conquistador europeo. Sin embargo, tales interpretaciones, a pesar de los esfuerzos conscientes o inconscientes de sus intérpretes, van a dar origen a ideas que serán a su vez una novedad para las ideas que el europeo tenía de su propia cultura, tanto en el sentido tradicional como en el nuevo.

En el presente trabajo no hago otra cosa que exponer, a grandes trazos, algo del espíritu propio de esta etapa de nuestra Historia de las Ideas desde el punto de vista sajón. Espíritu en cuyas ideas se van haciendo patentes muchas de las interpretaciones que sobre su propia historia harán, de sí mismos, los creadores de la Nación Norteamericana. Ideas que justificarán y perfilarán una interpretación del mundo y de la vida que van a serles propias. Ideas en pugna, desde sus inicios, con las de los colonizadores y creadores de las naciones iberoamericanas. Pugna que habrá de reflejarse en toda la Historia de América.

\section{Progreso contra Historia}

Los primeros colonizadores de Norteamérica vendrán a ser, por su actividad y las ideas que los animaron, los más claros exponentes del espíritu Moderno. Hombres surgidos de una nueva clase social en pugna con los estamentos sociales, políticos, económicos y religiosos de la agonizante etapa cultural de Europa conocida, en nuestros días, como Edad Media. Hombres con una nueva moral en pugna con la sostenida por las clases que habían hecho el viejo Orden Cristiano. Hombres sin acomodo alguno en el seno de estas clases: ni aristócratas ni plebeyos. Clase media sin arraigo en los segundos y sin posibilidad de ser como los primeros. Esta clase media, intermedia, a la que se ha dado también el nombre de burguesía, creará los elementos que le permitan establecer un nuevo orden en el que obtenga el lugar privilegiado. Nuevo orden que implicará la plena destrucción del antiguo con todos sus estamentos. Nuevo orden social apoyado en la creación de una nueva eco- 
nomía, una nueva religión y una nueva política. ${ }^{2}$ Nuevo orden social, económico, religioso y político que implicará a su vez la creación de todo un Nuevo Mundo. América será este mundo nuevo. En este Continente el hombre moderno llevará a sus máximos logros los ideales que le perfilan como hombre nuevo. El mismo hombre cuya aspiración se hacía ya patente en la palabra "Renacimiento". Esto es, en la aspiración por volver a nacer, renacer; empezar otra vez como si nada estuviese hecho.

Para este hombre la historia se presentará frente a sus afanes de reforma como lo negativo. En Europa el hombre nuevo tropezaba continuamente contra la historia. La historia era su mayor obstáculo. Las viejas clases privilegiadas encontraban en la historia la justificación de sus privilegios. La historia ungía y determinaba el presente y el futuro. La nobleza por un lado, la Iglesia por el otro, se apoyaban en varios siglos de historia. Una historia que hacía imposible toda alteración social, económica, política o religiosa. Dentro de esie determinismo, originado en el pasado, el nuevo hombre no tenía cabida. De aquí su anti-historicismo, su repulsa de la historia. La historia se le presentará como la causa de todas las desigualdades, como la fuente de todas las incomprensiones humanas, la raíz de todas las guerras, el origen de todos los fanatismos. ${ }^{3}$ Frente a la historia predicará la vuelta a los orígenes, esto es, a la Edad de Oro, al Edén perdido, al mundo natural. Había que empezar de nuevo, hacer otra historia.

El hombre nuevo niega la historia hecha, la historia propiamente dicha; pero no se queda en la $a$-historia. Quiere volver a la naturaleza, pero no para permanecer en ella, sino para reanudar un camino nuevo que le lleve a un mundo donde sí tenga un lugar, el mejor de los lugares. Cree en la historia, pero en la que puede hacer, no en la hecha. La vuelta a los orígenes es sólo una vuelta al punto de partida en el cual pueda él tomar la mejor de las iniciativas. No quiere cargar con las obligaciones de un mundo que no ha hecho; quiere empezar como si nada estuviese hecho, poniendo en crisis o crítica todo cuanto no tuviese sus orígenes en su propio y único afán de recreación. Ta] fué el ideal de los grandes creadores de la Modernidad. ${ }^{4}$

Abandonado el pasado como justificación del futuro que se quería alcanzar, el hombre nuevo recurrirá a una nueva idea, a algo de su propia creación, a algo que justificase sus aspiraciones, a algo que fuese la expresión de la bistoria en potencia, de la historia que aún no se había hecho pero podía hacerse; algo que pudiese iniciarse con todo hombre, con cualquier hombre;

2 Sobre este aspecto puede verse a R. H. Tawney, La religión en el orto del canitalismo, Editorial Revista de Derecho Privado, Madrid, 1936; E. Troeltsch, El protestantismo y el mundo moderno, Fondo de Cultura Económica, México, 1951; Max Weber, The Protestant Ethic and the Spirit of Capitalism, Talcott Parsons, London, 1930.

3 Ideal patente en los creadores de las grandes Utopías renacentistas. Véase Utopías del Renacimiento, Fondo de Cultura Económica, México, 1941.

4 Renato Descartes, El Discurso del Método. 
algo que no representase discriminación alguna, que fuese válido para todos los hombres sin distinción. Este algo fué su idea del Progreso.

Con la idea del Progreso el nuevo hombre podía justificar, por un lado su ideal de igualdad frente a un mundo en el que se le regateaba un puesto de privilegio; por el otro, una nueva forma de justificación de otra desigualdad, dentro del mundo que estaba creándose y en el cual esperaba tomar el lugar privilegiado. El progresar era algo que estaba al alcance de todos los hombres sin excepción; algo que dependía de cada uno de ellos. En este sentido todos los hombres eran iguales, semejantes; nada que no fuese el esfuerzo personal y único de cada uno de ellos justificaría la idea de progreso. Pero, y aquí está el otro lado de la cara, progresar era ya diferenciarse, ser distinto de otro, de ese otro u otros que no habían hecho nada por alcanzar este progreso. Nada estaba hecho, cada hombre era el autor de su propio bienestar o desdicha. Y este bienestar no era otra cosa que fruto de un esfuerzo personal, único $y$, por lo mismo, indiscutible. Todos los hombres, por el mismo hecho de existir, tenían derecho a las mismas oportunidades; tenían las mismas posibilidades. Pero realizarlas era ya algo que correspondía a la capacidad natural de cada uno de ellos.

Las diferencias que en el futuro se iban a establecer no serían ya justificadas históricamente sino naturalmente. Las diferencias en la nueva sociedad iban a provenir de la misma naturaleza, no de hechos pasados. En la sociedad no había sino dos tipos de hombres: los capaces y los incapaces. Iguales por sus orígenes naturales; pero diversos por las capacidades con que les había dotado la misma naturaleza. Los privilegios seguían existiendo, pero en esta ocasión se otorgaban por méritos de origen natural. Los privilegios no se heredaban, se adquirían; eran frutos de esfuerzos concretos, realizados por cada hombre en particular, por cada individuo. Los privilegios que no tuviesen este origen carecerían de vàlidez. Sin embargo, y aquí está otro aspecto de esta justificación, el progreso no era como una tela de Penélope que se hiciese y rehiciese; como un principiar. No era algo que todos los hombres podían principiar, aunque todos hubiesen tenido la misma oportunidad. Progresar era acumular; una acumulación sin fin de bienes materiales y por ende de privilegios sociales, económicos y políticos. El progreso alcanzaba una dimensión más amplia que la puramente personal de los individuos que lo hacían posible. Era algo propio de una clase, un grupo social o un pueblo como expresión destacada de esta clase o grupo social. Dentro de esta clase o grupo social lo realizado no era sino un punto de partida para lo que había de realizarse. Lo acumulado se recibía, no como una herencia, sino como un bien a partir del cual el individuo tenía que acumular otros. De esta su capacidad para acrecentar lo recibido dependía su pertenencia a la clase o grupo social privilegiado. No bastaba recibir, era menester acrecentar sin fin, más allá, inclusive, de las propias y personales necesidades. 
Se vuelve así a aceptar la historia pero como instrumento para un futuro siempre abierto. Lo acumulado servirá para ampliar, aún más, la acumulación. La nueva historia no justificará privilegios pasivos; éstos no podrán ser otra cosa que instrumentos para nuevas recreaciones. En esta historia los capaces no serán, después de todo, otra cosa que instrumentos de una entidad que se va perfilando como algo objetivo, impersonal, ajeno a los mismos individuos que lo hacen posible. O, algo más, como la expresión no humana ni concreta de los mismos. Algo semejante al Dios, que el hombre moderno empezó a poner entre paréntesis; pero dependiente del mismo hombre. Algo así como un Dios en el que todos los hombres se deificasen, sin ser concretamente ninguno de ellos. El Progreso venía a ser la deificación de la actividad creadora del hombre.

En esta forma el hombre moderno, a la vez que justificaba su nueva situación social, daba un sentido trascendente a su actividad, trascendencia que, a su vez, justificaba también la serie de privilegios que iba alcanzando. Tanto sus privilegios personales, como sus privilegios como grupo, clase social o puèblo, iban a quedar justificados por la nueva forma de trascendencia dada a sus esfuerzos. Una nueva deidad justificaba al hombre nuevo, como antaño otra divinidad había justificado al antiguo. El viejo determinismo fué substituído por otro nuevo. Un determinismo no menos absoluto que el primero, pero apoyado en el ente menos determinado de la Creación: el Hombre.

\section{Nuevo determinismo}

Apartado el nuevo hombre de un determinismo heterónomo -esto es, de un determinismo externo, ajeno-, crea un determinismo originado en sí mismo, en su propia voluntad, un determinismo autónomo. Aparentemente, e] hombre se presenta a sí mismo como instrumento de un ente que le es ajeno; llámase éste Dios como lo llaman los puritanos, Progreso como lo llamarán los ilustrados o Espíritu Absoluto como lo llamará Hegel. Y digo aparentemente, porque en realidad se trata de un ente cuya existencia depende del hombre mismo. Es éste el que lo hace posible, el que lo determina. La Divinidad, en cualquiera de estas expresiones, existe porque el hombre le da existencia con su obrar. Dios es producto de las obras del hombre. Sin el actuar humano la divinidad carecería de existencia: la bondad divina dejaría de ser patente, el progreso se detendría o el espíritu carecería de conciencia de sí mismo. Sin los hombres la naturaleza, aun existiendo por sí misma, carecería de ser. Nadie sería testigo de la bondad, la gloria o la justicia divina. El espíritu sería una fuerza ciega, sin expresión concreta, sin fines. Dios depende, en suma, del hombre. 'El hombre es, en última instancia, el creador de Dios. Este no es sino expresión del poder del hombre. Dios es todo lo que el hombre ha sido y es; pero más aún, lo que puede ser. Dios es la pura posibilidad humana, su 
futuro, su permanente poder ser; esa meta sin fin que el nuevo hombre ha creado para justificar su existencia.

En alguna forma todos los hombres, cada hombre, es un Dios o una parte del mismo. Su acción, mayor o menor, es la acción de Dios, el progreso o el espíritu. Dios, el progreso o el espíritu hablan por su boca, se expresan por sus obras. Por ello lo que se realiza es lo que debe ser, lo que no pudo o puede ser de otra manera. El hombre saca de sí mismo los elementos de su autotrascendencia. Su actividad, su acción concreta, se convierte en algo trascendente, en algo que va más allá de sus humanas limitaciones. El hombre se diviniza dando a su obrar un carácter trascendente. El, como hombre concreto, muere, desaparece, vuelve a la nada; pero su acción permanece. Sus obras lo inmortalizan. En ellas habla, no el hombre perecedero, sino el Hombre como instrumento de Dios, resorte del Progreso o conciencia del Espíritu. Tal Hombre está, por esta razón, por encima de los hombres concretos y efímeros; más allá de sus limitadas pasiones, deseos o anhelos; éstos deberán ser sacrificados para la realización de los altos fines perseguidos por el Hombre; pues tales fines no son, ni pueden ser, otros que los de Dios, el Progreso o el Espíritu. Sólo cuando las pasiones, deseos o anhelos del hombre coinciden con estos fines, su acción tiene éxito. Todo lo que se aparta de estos fines fracasa; porque nada puede detener o cambiar la marcha de Dios, el Progreso o el Espíritu.

De esta forma el nuevo hombre ha sacado de sí mismo un nuevo determinismo. Un determinismo que hace de su obrar, concreto, el Obrar propio de la Divinidad, cualquiera que sea el nombre que le dé. Obrar que se convierte en orientación, dirección o guía de toda actividad humana. Obrar con un sentido, el propio de los fines de esa divinidad que parece orientarlo. Sin embargo, en realidad, no se trata de otros fines que los de un determinado hombre, grupo o clase social. ${ }^{5}$ Mediante este nuevo determinismo el grupo que arriba a la Historia justifica sus pretensiones de privilegio. El hombre que toma la iniciativa en el Mundo Moderno hace de su concreto obrar y sus fines el único obrar válido y los únicos fines a realizar. Todo interés o actividad que se aparte de estos fines carecerá de sentido y por ende de justificación. Faltos de justificación, los intereses que se alejen de los de la nueva clase social tendrán que eliminarse o ser eliminados. Grupos sociales, sociedades o pueblos cuyos intereses sean opuestos, o diversos, a los del nuevo grupo, tendrán que someterse o exponerse al exterminio. Su destino, si han de sobrevivir, es el de servir a estos nuevos fines. Estos fines serán sus propios fines. Sólo dentro del nuevo orden Teológico-Político de los puritanos, el orden establecido por las naciones que representan el progreso, o el orden que expresa la toma de Conciencia de la Cultura Occidental, es posible la supervivencia.

5 Primero el Marxismo, después la llamada Sociología de la Cultura, han puesto de manifiesto el transfondo económico o social que se oculta en las diversas ideologías de acuerdo con los intereses de los grupos o clases que las sostienen. 
Los hombres, pueblos o naciones que se aparten de este orden están fuera de todo orden que justifique su existencia. No serán otra cosa que expresiones del Mal, la barbarie o la animalidad de lo irracional.

Toda acción contra estos hombres, pueblos o naciones no tan sólo queda justificada, sino que, además, viene a formar parte de la misión que Dios, el Progreso o el Espíritu han señalado al nuevo hombre o grupo social predestinado a ser su instrumento constructivo. Vencer al Mal, en cualquiera de sus expresiones, e incorporar a los hombres y a los pueblos a Dios, al Progreso o el Espíritu, es la elevada misión de los hombres y pueblos que los representan en esta tierra. Por ello su acción tiene y tendrá siempre éxito. Siempre prevalecerá el Bien frente al Mal. Todos sus éxitos serán expresión del primero, todos los obstáculos a su fines, del segundo. ${ }^{0}$ Obstáculos sobre los cuales siempre triunfarán, porque así ha sido escrito, porque así tiene necesariamente que suceder.

\section{Encuentro con América}

El nuevo europeo cansado ya de un mundo sobre cuyo orden no se le había pedido opinión, un orden que enajenaba su libertad, se lanzó a la búsqueda de un mundo nuevo donde empezar desde los orígenes. Este mundo se le hizo patente en América. El Nuevo Continente llenaba sus aspiraciones al presentarse como un mundo libre de compromisos sociales, económicos, políticos, religiosos o de cualquier otra especie. Se trataba de un mundo que podía ser hecho desde sus cimientos. Un mundo por hacer, de acuerdo con la propia razón. ${ }^{7}$ Un mundo planificado, uniforme, con leyes "claras y distintas" como el orden racional. 8 Un mundo en el que la igualdad proclamada para todos los hombres fuese una realidad. Una igualdad que fuese el punto de partida para ese otro tipo de desigualdad que ya hemos analizado. Esto es, un mundo que diese oportunidades a todos los hombres para mostrar su destino. Destino que se hará patente en la capacidad o incapacidad de estos hombres para una acción creadora. En este mundo no contarán más los privilegios apoyados en valores tradicionales. En este mundo cada hombre será el creador de su propio bienestar, el autor de sus propios privilegios.

Sin embargo, en esta América, y a pesar de las pretensiones del europeo, existían otros hombres con otra cultura. Pueblos de culturas muy adelantadas, como la de los aztecas en México y los incas en el Perú; o pueblos de cultura aún incipiente, como la de los indios que poblaban las llanuras y bosques del Norte de América, pero con una visión del mundo y de la vida distinta del

- Arnold J. Toynbee en el tomo VI de su Estudio de la Historia ha hecho patente esta actitud al referirse a los Determinismos como una expresión de lo que llama "Cisma en el Alma" en la "Desintegración de las Civilizaciones".

7 Descartes: op. cit.

8 Tomás Moro, Utopía, en op. cit. 
europeo. Estos hombres eran poseedores de un pasado, de una tradición más o menos elevada o más o menos rudimentaria. Una tradición que estaba en làs antípodas de la representada por sus descubridores, conquistadores y colonizadores. Frente a ella no cabía otra actitud que eliminarla para imponer sus propios puntos de vista $y$, con ellos, sus intereses. Sin embargo, frente a los europeos se alzaban otros hombres; al menos eso parecían. ¿Eran éstos sus semejantes? ¿Lo eran a pesar de la diversidad de sus costumbres? Y si lo eran, ¿cómo explicar esta diversidad?

Para el europeo que aún no se desembarazaba de su tradición cristiana original, el católico representado por los grupos que conquistaron y colonizaron América en nombre de los reyes católicos de España y Portugal, el problema se planteó en cuanto a la forma como poder hacer entrar a los indígenas en los cuadros de orden establecidos por la Cristiandad. El problema giró en torno a la naturaleza del indígena. Naturaleza que parecía reacia a someterse a los cuadros de orden cristiano. Naturaleza que se hacía patente en su extraña religión, moral y costumbres tan diversas del Cristianismo. ${ }^{9}$ Esta diversidad les hacía presentarse como algo menos que hombres. Bárbaros, les hubiera llamado Aristóteles; bestias, les llamaba un Sepúlveda. ${ }^{10}$ Bestias, desde el punto de vista de la idea que sobre el hombre tenía el Cristianismo; así como bárbaros partiendo de la idea que sobre el hombre tenía el helenismo. Bestias eran los hombres, que aun siendo naturalmente hombres, se encontraban fuera de la cultura cristiana; como bárbaros eran los hombres que, aun siendo hom. bres, tartamudeaban el griego por no estar dentro de la cultura helénica. ${ }^{11}$ Era el mismo tipo de bestialidad en que podía caer el mismo cristiano que se apartase de la Iglesia, violando las leyes éticas y sociales del Cristianismo. Bestialidad originada en el pecado, esto es, en la violación del orden divino. Bestialidad originada en el abandono de Dios, ya sea por propia voluntad o por engaño del demonio. Este era, precisamente, el caso de los indígenas americanos. Su bestialidad provenía de un engaño realizado por el maligno. Eran hombres que vivían como si fueran bestias ${ }^{12}$ por seducción del demonio. La diversidad cultural quedaba explicada por el diverso origen de sus culturas. Sólo una era buena y verdadera, la cristiana. Cualquier otra que la contradijese tenia que tener su origen en el diablo. ${ }^{13}$ Dios, por designios que sólo

9 Edmundo O'Gorman: "Sobre la naturaleza bestial del indio americano." Filosofía y Letras, Revista de la Facultad de Filosofía y Letras, Universidad Nacional Autónoma de México; núms. I y 2, México, 1941.

10 Juan Ginés de Sepúlveda: Tratado sobre las justas causas de la guerra contra lós indios. Fondo de Cultura Económica, México, 1949.

11 José Gallegos Rocafull: El pensamiento mexicano en los siglos xvi y xvii. Centro de Estudios Filosóficos, Universidad Nacional Autónoma de México. Imprenta Universitaria, México, 1951.

12 Interpretación que ofrece Edmundo O'Gorman en su op. cit.

13 Luis Villoro: Los grandes momentos del indigenismo en México, El Colegio de México. México, 1950. 
él conocía, había mantenido a todo un Continente fuera de su seno. Esto es, fuera de la tradición y orden cristianos, fuera de la cultura cristiana. El problema quedaba resuelto incorporando a estos pueblos a la Cultura Cristiana. Tal fué la tarea que se asignaron los misioneros de las diversas Órdenes católicas que evangelizaron, primero Iberoamérica y luego el Canadá. Incorporaron, no sólo al indígena como individuo, sino también su cultura. En ella supieron encontrar, no sólo diferencias de origen diabólico, sino también semejanzas de origen divino. ${ }^{14}$ Se trataba de hombres de un mismo origen, creados por el único creador, hombres que habían olvidado a Dios por una acechanza del demonio; pero que en muchos de sus hábitos y costumbres lo recordaban. Los misioneros supieron encontrar muchos hábitos y costumbres en los que se hacía patente su cristiano origen, por lejano que pareciese. Mediante la adaptación cristiana de estos hábitos y costumbres se logró una fácil reincorporación del indígena a la cultura que le devolvía su calidad humana. El pasado, la tradición, la cultura indígena fueron incorporados, en los aspectos que no chocaban, a la tradición y cultura cristianas. Sobre los fuertes cimientos de la cultura indígena montaron los misioneros la cultura católica representada por España, Portugal y Francia. Algo semejante hicieron los conquistadores al levantar sus nuevas ciudades sobre los cimientos construídos por los indígenas en las grandes capitales de México y el Cuzco.

Otra será la actitud del europeo cuyo programa fué el desembarazarse de la tradición para construir la que pudiese considerar como propia. Un hombre como él, tan poco dispuesto a aceptar su propia historia y tradición, iba a estar menos dispuesto a aceptar una tradición, hábitos y costumbres que nada tenían que ver con las que él tenía que aceptar provisionalmente ${ }^{15}$ menos aún con las que él iba a crear. Para ser lógico con la idea que tenía de lo humano, aceptaba en principio la humanidad de los indígenas. Estos eran hombres como él, poseedores de esa razón que los iguala a todos; pero cuya rudimentaria cultura indicaba que no habían sabido hacer buen uso de tal don. La vida natural, libre de compromisos, que le parecía buena como punto de partida, le farecía también mala como permanencia. La vuelta a la naturaleza, a los orígenes, era buena para desembarazarse de compromisos no adquiridos personalmente; pero mala como un programa de vida. El indígena, que el europeo presentaba al Viejo Mundo como un modelo de sencillez cultural frente a la complicada cultura europea, era, por otro lado, un mal modelo para el espíritu de acción del nuevo hombre. El indígena era un semejante desde el punto de vista de los orígenes; pero dejaba de serlo en cuanto a los fines. El indígena no tenía más meta o fin que vivir en, con y de la naturaleza; el europeo quería algo más: dominarla. El primero se identificaba con ella, el segundo se la

14 Véase Fray Bernardino de Sahagún: Historia general de las cosas de Nueva España. Edit. Pedro Robredo, México 1938, 5 vols.

15 Descartes, op. cit. 
incorporaba. Para el nuevo europeo el indígena y la naturaleza terminaban identificándose. El europeo no se identificaba; él era precisamente el hombre que se independizaba de ella, la dominaba y sometía a las necesidades de su cultura. El indígena no; confundido como estaba con la naturaleza, perdía su calidad humana y se convertía también en un elemento dominable, como dominable era la flora, la fauna y el suelo natural. ${ }^{10} \mathrm{El}$ hombre que no había sabido dominar sus llanuras, sus bosques y sus ríos rebajaba su humanidad convirtiéndose en un salvaje. Mejor dicho, no la rebajaba, porque rebajar implica haber tenido ese algo que se rebaja. No, el indígena no había alcanzado su calidad humana, no era más que un proyecto de hombre. Esto es, no había evolucionado, progresado. La calidad de hombre se adquiría venciendo a la naturaleza, dominándola, libertándose de ella. Esto es lo que no había hecho el indígena; era por ello un primitivo. Sólo adquiriendo las cualidades constructivas de los europeos modernos podría incorporarse a la Humanidad o Civilización. Sólo bajo la protección y servidumbre de los hombres o pueblos que dominaban la naturaleza, podría tener esperanza de que algún día se convirtiese nuevamente en un semejante. Sólo entonces se incorporaría a la civilización y al progreso. ${ }^{17}$

\section{América dentro del orden puritano}

El europeo moderno que se ha encontrado con América empieza viéndola, al igual que el tradicionalista, a través de un punto de vista religioso. Sólo que este punto de vista se lo va a dar una nueva interpretación del Cristianismo: el Calvinismo. El Puritanismo que se deriva de esta doctrina dará a sus seguidores un instrumental lo suficientemente amplio para justificar sus nuevas aspiraciones y, con ellas, los privilegios que han de derivarse. El Calvinismo se va a presentar como la doctrina más adecuada a los intereses y aspiraciones del nuevo hombre. Se trata de una nueva Iglesia. Una Iglesia cuya tradición empieza con su creador. Una Iglesia que empieza por poner en tela de juicio a toda la organización eclesiástica establecida por el Catolicismo. Desconociendo toda autoridad tradicional establece sus propias autoridades. Sus fieles son nuevos cristianos que vienen a establecer el auténtico orden cristiano. Estos vuelven también a los orígenes del Cristianismo, a las Sagradas Escrituras, a la Biblia. Partiendo de estos orígenes inician la créación de la nueva Iglesia, la construcción de la Nueva Jerusalem. Dentro de la misma construyen un nuevo orden teológico-político. Un orden en el que lo divino y lo humano se mezclan. Los fieles no son otra cosa que intérpretes de Dios y realizadores de sus designios.

16 Interpretación propia del Mundo Occidental para justificar su expansionismo. Véase Estudio de la Historia, "Introducción", de Arnold J. Toynbee.

17 Toynbee, op. cit. 
El punto de partida de la Nueva Iglesia es, como la de todo el Modernismo, el individuo. La Nueva Iglesia lucha contra toda autoridad eclesiástica que no se justifique ante la razón de los fieles. Hay una especie de relación directa entre Dios y los fieles a través de la razón que se hace patente en la interpretación de la Biblia. Dé su propia conciencia saca el nuevo cristiano los elementos sobre los cuales fundar la Nueva Iglesia. No acepta la existencia de un poder eclesiástico que salve al hombre; la salvación es obra personal, algo que cada hombre debe alcanzar por sí mismo. Y esto se logra mediante la humildad, la obediencia y la confianza en Dios. El hombre tiene una misión en la tierra, y sólo siendo fiel a esta misión podrá salvarse. La fidelidad a la misión se hace patente en los hechos. Su misión es establecer el reino de Dios en la tierra. De aquí ese su afán por plasmar el mundo de acuerdo cun esta misión; afán por doblegar a los condenados bajo el reconocimiento de la ley divina. De aquí también ese afán por mantener, con todo su rigor, una comunidad cristiana que sea expresión de la mayor gloria de Dios. ${ }^{18}$ Fl mundo, lejos de ser un lugar de destierro, debe ser el escenario de la acción divina a través de la humana. El ascetismo, a la manera del Cristianismo antiguo, no tiene cabida en la nueva religión. El mundo, como el hombre, es una criatura de Dios, expresión de su gloria. Es el lugar donde el cristiano puede hacer patente su vocación; esto es, su capacidad o incapacidad para atender a su misión. Es en la acción sobre el mundo donde el nuevo cristiano encontrará respuesta a sus anhelos de salvación. Dominar la naturaleza, transformarla en obras, es glorificar a Dios. La gloria de éste depende de la capacidad del hombre para transformar el mundo. De aquí que reclame el aprovechamiento sistemático de todas las posibilidades de la acción humana. Todo lo que pueda contribuir al progreso y la prosperidad del cristiano, al mejoramiento de la Comunidad Cristiana, contribuye a dar a Dios mayor gloria. De aquí también que el puritano considere su trabajo como una actividad encaminada a dar mayor gloria a Dios y mayor honor a su comunidad. A mayor trabajo, mayor gloria y honor. No se trabaja por lo puro y simplemente necesario; se trabaja para acrecentar algo que trasciende las necesidades propias del hombre. No basta tener lo necesario, es menester acumular, capitalizar. ${ }^{19}$ El trabajo, el obrar puro, deja de ser un medio y se convierte en un fin del hombre. Lo logrado, lo alcanzado, no es sino capital para una nueva y más amplia inversión. El trabajo por el trabajo, el obrar por el obrar, el acumular por el acumular, tendrán sus antecedentes en este trabajar, obrar, actuar y acumular por la mayor gloria de Dios en este mundo.

Ahora bien, este actuar y acumular que empieza por ser para la mayor gloria de la divinidad acabará por ser para la mayor gloria y provecho de quien actúa y acumula. "En el ascetismo intramundano-dice Troeltsch- se

18 E. Troeltsch, op. cit.

19 R. H. Tawney, op. cit. 
alberga un antagonismo entre el cielo y la tierra, y en este antagonismo, la tierra le ha ganado la partida." ${ }^{20} \mathrm{El}$ hombre que empieza buscando en sí mismo a Dios termina confundiéndolo con su propia persona. La pugna que se había establecido entre los bienes de este mundo y la salvación en el otro encuentra la solución adecuada haciendo a los primeros un índice del logro de la otra. El triunfo en la tierra va a ser el mejor índice de que se alcanzará, también, el triunfo celeste. De acuerdo con esta idea, el hombre que actúa y domina al mundo cumple con la misión que le ha sido encomendada; y cumpliéndola alcanza también su salvación. Es más, el hombre que actúa y triunfa resulta ser algo más que un hombre: es un instrumento del Creador. Dios es el que habla en sus obras. La acumulación de bienes materiales deja de ser índice de avaricia porque se convierte en instrumento para una acción, cada vez más creciente.

Frente a este tipo de hombre están los indígenas, los hombres con los cuales se ha encontrado en América. Estos no entienden nada del trabajo por el trabajo, de la acción por la acción. El indígena reduce su trabajo al simple ligro de lo que considera estrictamente necesario. No acumula, vive prácticamente al día. De la naturaleza no toma sino lo puramente necesario. No la domina, no la transforma, simplemente vive de lo que ella le provee graciosa. mente. Se trata de hombres, si se les puede dar este nombre, que se han apartado de su misión.

Con estos hombres, los puritanos colonizadores de Norteamérica no tienen otra liga que la de sus orígenes: el pecado. Son sus semejantes en cuanto son hijos de Adán y herederos del primer pecado. Pero son distintos en cuanto los indígenas han permanecido en el pecado y los colonizadores se han esforzado en vencerlo. El Demonio ha logrado establecer su imperio en América gracias a estos hombres. El predicador de Boston, Cotton Mather, decía: "No sabemos cuándo ni cómo estos indios comenzaron a ser habitantes del gran continente; pero podemos conjeturar que probablemente el Demonio atrajo aquí a estos miserables salvajes con la esperanza de que el evangelio de Nuestro Señor Jesucristo no vendría nunca a destruir o perturbar su imperio absoluto sobre ellos." ${ }^{21}$ La misión de los colonizadores de América es precisamente la de rescatar al gran continente de las garras del Demonio. Algo semejante han pensado los misioneros católicos en el Sur de América; pero la solución, el rescate, la han intentado por otros medios: ${ }^{22}$ incorporando a los indígenas al Catolicismo.

El colonizador puritano se mostrará pronto incapaz para lograr esta incor-

20 E. Troeltsch, op. cit., p. 95.

21 Lewis Hanke, La lucha por la justicia en la conquista de América. Editorial Sudamericana, Buenos Aires, 1949; p. 19.

22 Véase Luis Villoro, op. cit. 
poración, aunque la intenta. ${ }^{23} \mathrm{Su}$ concepción religiosa va a ser el principal obstáculo en esta incorporación. El puritano parte del supuesto de que la luz que le ha permitido orientar su trabajo hacia esa colaboración terrestre con Dios es una luz que no se da a todos los hombres. Se trata de una gracia; esto es, de algo gracioso, gratuito, que sólo se da a determinados hombres. E] puritano, por la expresión de sus obras, parece ser uno de esos hombres que han recibido la gracia. Este ha sido llamado, avocado, por Dios para una misión que debe realizar en la tierra. Su misión en América es predicar y difundir la religión cristiana entre los indígenas, para dar a éstos la oportunidad de que se salven y escapen de las garras del Demonio. Pero se trata sólo de una oportunidad al alcance de los que estén predestinados a salvarse. Estos, si los hay, recibirán también el llamado, sentirán la avocación, y se incorporarán al Nuevo Orden Cristiano. Pero este llamado, esta avocación, es algo que sólo depende de Dios; nada pueden hacer los hombres por darlo a otros o alcanzarlo. "Dios -decían ya los primeros observadores que iniciaron la colonización de Norteamérica- no ha permitido que una gracia tan abundante como lo es la luz de su palabra y conocimiento de él les sea revelada a aquellos infieles antes del tiempo fijado para ello." 24 Los colonos no podían hacer otra cosa por los indígenas que ofrecerles los medios mediante los cuales la gracia, si existía, se pudiese hacer manifiesta. Lo primero era incorporarlos a su orden. Someterlos con sus personas y bienes para darles la oportunidad de vivir en forma semejante a la de los colonizadores, que éste sería el primer paso hacia la posible manifestación de la gracia. "Si a cambio de todos sus bienes sólo recibieran el de ser convertidos al Cristianismo -dicen-, podrían darse por bien recompensados." 25

$\mathrm{La}$ incorporación de los indígenas, con sus bienes, al orden puritano no garantizaba la obtención de la gracia, como puede ya deducirse. Dentro de este orden, como se anticipó, la gracia se hacía patente en el éxito logrado sobre la naturaleza, éxito que tomaba un carácter material. Este éxito difícilmente podían alcanzarlo los indígenas en competencia, dentro de la cual estaban vencidos de antemano, con sus colonizadores. Aun aceptando la mejor buena fe de éstos, era difícil que los indígenas pasasen, de un salto, de un tino de vida natural y una organización social casi primitiva al tipo de vida religiosa propia del Calvinismo y a su organización social. Allí no tenían más recurso que scmeterse indefinidamente, sin grandes posibilidades de salvar el alma, o regresar a su vida natural. En cualquier caso, el puritano miraba tal cosa como una demostración de que Dios no había llamado al indígena. La dificultad de éste para adaptarse a una sociedad que estaba en las antípodas de la propia era vista como la más clara señal de su baja humanidad. La huída, la vuelta

23 Juan A. Ortega y Medina, El horizonte de la evangelización anglosajona en Norteamérica. Tesis para Doctorado, prox. publicación.

24 Ortega, op. cit.

25 Ortega, op. cit. 
al mundo natural, era también -vista como el triunfo del Demonio sobre el indígena. Definitivamente el hombre americano, el indígena, está perdido. Nada se podía hacer por él para redimirlo. Sólo el indio, con sus propias fuerzas, podría alcanzar esta redención, ponerla de manifiesto: su fracaso para adaptarse al nuevo orden era una prueba de su lejanía de Dios.

Deducido esto, se podría también deducir el derecho que asistía a los colonizadores para dominar la tierra americana. Dios les había donado esta tierra para hacerla fructificar. Su gloria se haría patente mediante estos frutos. Se trataba de una tierra virgen, nueva, sin historia. Tierra propia para hombres nuevos que estaban dispuestos a hacer la nueva historia sagrada. Una historia hecha con sus propias manos, con el fruto de sus mejores esfuerzos. En esta tierra y la historia que con ella se iniciaba, no tenían cabida los indígenas. Nada habían hecho éstos por transformar las tierras que ahora adquirían la fisonomía que el nuevo hombre les estaba imponiendo; nada habían hecho tampoco al ser incorporados en el nuevo orden; todo lo contrario, lo habían obstruído para mantener sus primitivas formas de vida. El indígena no sólo era un estorbo para el orden teológico, o el orden de la civilización, además era un peligro para la salvación de los cristianos. El puritano, una vez convencido de la imposibilidad de incorporar a los indígenas al nuevo orden, se convenció también de que podrían contaminarlo, esto es, alejarlo de su avocación, apartarlo del llamado divino. El indígena, por su persistencia en un mundo no cristiano, se convirtió en algo más que un desamparado de Dios, en algo más que un desgraciado; su persistencia en el mundo que le era propio será vista como persistencia en el mal; como expresión del mal mismo. El indio era el mal encarnado, como el puritano era el bien.

Junto con el indígena encarnaron al mal sus diversas expresiones físicas, sociales y morales. El color de su piel, su incapacidad para determinadas técnicas, la diversidad de sus hábitos y costumbres, fueron también considerados como expresiones del temido Mal. Todo lo diverso al color de la piel, hábitos y costumbres del colonizador blanco empezó a verse como lo que debería ser evitado. El temor a una contaminación moral se expresó como discriminación física. Se consideró que, evitando toda contaminación física con hombres que parecían encarnar el mal, se evitaría ser contaminados por éste. El mal se presentaba encarnado en la raza, en la pobreza, en la incapacidad de esta raza para adoptar los instrumentos, hábitos y costumbres propios de la raza que mostraba con éxito su predestinación.

Fué así como el indígena, el hombre natural originario de esta América, el hombre que se presentaba como un modelo en Europa, se convirtió en algo que debería ser evitado. Fué el primer discriminado para la mayor gloria de Dios y el mayor triunfo del Bien. Los puritanos, incapaces de incorporar al indígena a su orden, decretaron su expulsión y ordenaron se evitase cualquier contaminación con el mismo. Toda mezcla con los indígenas quedó prohibida. 
A diferencia del Catolicismo en Iberoamérica, se prohibió el matrimonio con indígenas y se castigó toda relación carnal con los mismos; de aquí se pasaría a prohibir cualquier relación social en la que se les igualase. El puritanismo se impondrá, además, la misión de ensanchar los dominios del bien sobre los del mal. Arrancar las tierras americanas de las inhábiles y diabólicas manos de estos engendros del mal sería una gran tarea por cumplir. La implicación de las fronteras colonizadas como ampliación del mismo bien fué la mejor y primera justificación encontrada por estos hombres que anhelaban avanzar siempre. Toda la ambición, los incontenibles anhelos del hombre moderno, encontraron así una justificación religiosa en su expansión sobre América. Todo lo que no coincidió con sus puntos de vista y sus intereses fué visto, de acuerdo con la interpretación religiosa que adoptaron, como expresión del mal. Con éste va a identificarse todo lo que sea opuesto a sus intereses. Este punto de vista marcará, ya desde sus inicios, las relaciones entre las dos Américas: la Sajona y la Latina. En un principio será dentro de las difíciles relaciones que podrían guardar dos puntos de vista religiosos tan opuestos como el Calvinista y el Católico; después, dentro de la misma diversidad cultural entre una y otra América y la diversidad de sus intereses. Ya en esta etapa de la historia de América los supuestos justificativos serán otros.

\section{Puritanismo y Democracia}

El Puritanismo como expresión religiosa de los ideales del hombre moderno ofrecerá, dentro de la organización social a que dió lugar, los elementos ideológicos que han hecho de los Estados Unidos la cuna de la Democracia Moderna. El protestantismo, en general, empieza por representar al espíritu individualista en lucha contra el absolutismo religioso. Dentro de él se desarrolla la libertad de examen e interpretación religiosa. No existen verdades absolutas sino a través de los individuos que las interpretan. Son los individuos los que se encuentran en relación directa con Dios a través de sus respectivas comunidades. Pero comunidades organizadas de acuerdo con el ideal moderno del Contrato Social.

Por lo que se refiere al puritanismo, esta idea de una comunidad, apoyada en la libertad de los individuos que la componen, forma el meollo de su organización social. Siguiendo a Calvino sostienen que el papel del Estado es el de mantener el culto de Dios, preservar la pureza de la doctrina religiosa, defender la constitución de la Iglesia, regular las vidas de acuerdo con lo que requiere una sociedad humana, ordenar las costumbres con la justicia civil, promover la concordia y establecer la paz y la tranquilidad social. ${ }^{26}$ La organización social no es algo que el individuo encuentra simplemente hecho, sino un

26 Cita de Calvino hecha por Ralph Barton Perry en su libro Puritanism and Democracy, The Vanguard Press, New York; p. 116. 
compromiso que el mismo adquiere para alcanzar la paz que ofrece la seguridad. Los límites sociales que establece la sociedad son límites que el mismo individuo se impone para alcanzar seguridad. Las comunidades tienen su origen en la voluntad de los individuos que las establecen para garantizar su bienestar en este mundo y la posibilidad de su salvación en el otro. Viviendo de acuerdo con los intereses de la comunidad y las leyes divinas la doble seguridad se hace posible. Mediante pactos con Dios y con los hombres se crean los lazos que ofrezcan la doble seguridad. En las comunidades puritanas establecidas en las primeras colonias de Norteamérica la Iglesia viene a ser el centro de esta doble seguridad. "El poder civil -dice Angélica Mendoza- quedó subsumido en el religioso y la norma civil se sometió a la regulación eclesiástica pasando la dirección total de la vida ciudadana a manos de las congregaciones." ${ }^{27} \mathrm{La}$ Iglesia tiene como fin establecer el reino de Dios entre los hombres, con lo cual se garantiza la doble seguridad a los individuos que permanezcan dentro del orden social y religioso establecido por ella. Dentro de este orden el individuo guarda para sí un conjunto de libertades tanto en el plano económico como en el del conocimiento. El uso de su razón queda garantizado dentro de esta organización, al igual que el mejor uso de sus bienes materiales. Se equilibra el orden con la libertad. Es más, con el tiempo, la libertad se irá imponiendo sobre el orden dentro de los límites necesarios para garantizarla.

El orden calvinista, a pesar de su rigidez, permitió en América la formación de las primeras comunidades democráticas. Se trataba, como ya se ha dicho, de una especie de Contrato Social, de una relación que obligaba al individuo voluntariamente a ceder un mínimo de su libertad para garantizar el orden y, por ende, su propia seguridad. De acuerdo con Hobbes, el individuo, para alcanzar la felicidad que no le proporciona su incontenible afán de poder, dominaba éste y alcanzaba la felicidad por la vía de la seguridad. Sin cmbargo, una vez aceptada la comunidad, firmado el pacto, los funcionarios de la Iglesia no respondían sino ante Dios, estableciendo así una especie de Teocracia de origen democrático. "La teoría era democrática en cuanto que abría el camino a la elección regular de magistrados y ministros de la Iglesia por determinación de todos los miembros -dice Herbert W. Schneider-, y en cuanto que propugnaba por la igualdad y el gobierno representativo; pero en otro sentido no era democrática, puesto que negaba que los funcionarios elegidos fueran responsables ante la voluntad del pueblo, y afirmaba que la ley y la autoridad provienen de Dios." 28 La intolerancia a que dió origen esta afirmación, de parte de los citados funcionarios, dará en el futuro origen a diversas reacciones que habrán de culminar con la explicitación plena de la ideología

27 Angélica Mendoza, Fuentes del pensamiento de los Estados Unidos, El Colegio de México, México, 1950; p. 13.

${ }_{28}$ Herbert W. Schneider, Historia de la filosofía norteamericana, Fondo de Cultura Económica, México, 1950; p. 16. 
liberal democrática lograda por los "Ilustrados" que realizaron el movimiento de Independencia de los Estados Unidos.

Así, una teoría contractualista creada por el puritanismo europeo para minar, en parte, los privilegios del sacerdocio y el poder de las instituciones eclesiásticas al someterlas a la elección de sus miembros, se convirtió en América en un sistema que sirvió de base a la organización democrática de las Colonias Sajonas. En Nueva Inglaterra, dice Schneider, resultó práctico organizar, "por pactos o contratos sociales, pequeñas comunidades independientes, ciudades o congregaciones, pequeños reinados de Cristo, o teocracias, en que magistrados y ministros de la Iglesia, elegidos por voto popular, eran conjuntamente responsables del cumplimiento de la ley de Dios". ${ }^{29} \mathrm{El}$ ideal del hombre moderno, de un mundo donde pudiese iniciar toda organización social desde sus principios, se hace posible en América. El pacto social, la aceptación voluntaria de compromisos sociales, se hizo posible en este Continente. No más compromisos no adquiridos libremente; no más leyes o reglamentos impuestos por tradición alguna. En América el individuo establecía libremente estas leyes y reglamentos; así los compromisos adquiridos eran sus compromisos.

El factor teocrático, que aún se hacía patente en la constitución de estas comunidades que tenían como centro a la Iglesia, fué minado poco a poco. "Aunque los ministros de Nueva Inglaterra se habituaron a promulgar decretos divinos desde los púlpitos y se abrogaron poderes y modales de estamento privilegiado -dice Schneider-, los seglares, a la larga, insistieron en sus derechos contractualistas, y minaron, de grado en grado, las teocracias clericales en favor de las democracias." ${ }^{30}$ Fué inútil el clamor de la clerecía contra esta reacción, inútiles fueron sus condenas contra esta supuesta impiedad; las nuevas generaciones fueron forjando el orden democrático que servirá de ejemplo a otras sociedades en el mundo. "En otras palabras -sigue Schneider-, lo que fué en Europa, primariamente, una revuelta de la clase media en contra del privilegio eclesiástico, se convirtió en América en una base positiva en que asentar las comunidades políticamente independientes, en las que la clerecía perdió gradualmente su poder y conservó su prestigio sólo en la medida en que se resolvió a compartir el punto de vista seglar." 31 En las comunidades a que dió lugar el Calvinismo en la Nueva Inglaterra se entremezclaron los diversos intereses del que hemos llamado Hombre Moderno. Su preocunación por dominar el mundo sin perder, por otro lado, la posibilidad de su salvación en el cielo, quedó garantizada. La nueva Iglesia sancionaría su libertad económica y su expansionismo al mismo tiempo que vigilaría su alma. "Las ciudades de Nueva Inglaterra no fueron ni meros refugios de mercaderes aven-

29 Op. cit., p. 18.

30 Op. cit., p. 19.

31 Op. cit., p. 19. 
tureros, ni santas repúblicas; pretendieron ser ambas cosas - dice Schneider-, pero de grado en grado se fué desenvolviendo un tipo distinto de independencia que entrañaba una mezcla de idealismo platónico y prosperidad mercantil de tipo yanqui. La 'elección' y la 'providencia' de Dios vinieron a ser la sanción ideológica de las comunidades autónomas." ${ }^{32}$

\section{La Comunidad de los Elegidos}

La pertenencia a estas comunidades, de formación democrático-teocrática, será considerada como un privilegio para sus asociados. Pero un privilegio de origen divino, una especie de selección realizada por la Divinidad. Estas organizaciones comunales venían a ser la encarnación de la Ciudad de Dios en la tierra. Los pactos que constituían estas comunidades alcanzaban su máxima sanción en Dios. Los puritanos de la Nueva Inglaterra organizaban sus colonias en una serie de pactos: "el pacto de la gracia", "el pacto eclesiástico" y el "pacto civil"."33 Por medio del primer pacto se establecía una alianza con el mismo Dios. Alianza entre el mundo espiritual de los hombres que eran justos y piadosos y la Divinidad; pacto sólo válido para los "santos", para aquellos que Dios conoce como tales. Mediante el "pacto eclesiástico", el pacto de "gracia" fué explicado, reconocido y recibido por los miembros de las congregaciones; éste enlazaba lo espiritual con lo mundano. En cuanto al "pacto civil", vino a representar el orden propiamente mundano mediante el cual se admitía la intervención del Estado para organizar las actividades de los individuos, regular sus personales existencias y asegurar la salvación de todo el grupo.

El fundamento de la sociedad puritana se encontraba así en el primer pacto. Es la elección y la providencia de Dios la que la sanciona. Esta sociedad es posible gracias a que hay "santos" que se enlazan con la Divinidad. Los hombres justos y piadosos como expresión de la gracia divina garantizan e] orden puritano. Dios garantiza este pacto que está por encima de los otros. Por encima de las responsabilidades civiles, tienen los individuos otra relación: la moral con Dios. Es esta relación la que se establece mediante el "pacto de gracia"; una relación sin mediadores, dentro de la propia alma, relación directa con Dios. El individuo se compromete a llevar una vida recta, sin tacha. Una vida cuyo centro sea el dominio de las pasiones como medio para alcanzar la santidad que le haga patente la gracia. Tanto el pacto eclesiástico como el pacto civil dependerán, para su éxito, de la realización del primero.

Ya se ha visto la importancia que tiene el trabajo dentro de esta organización. El puritanismo hace del trabajo de sus congregantes una manifestación de la gracia esperada. La vida recta y sin tacha se hace más explícita con la acción. No basta contemplar a Dios, es menester glorificarlo con el trabajo.

32 Op. cit., p. 19.

33 Véanse las citadas obras de Ralph Barton Perry y Angélica Mendoza. 
El Justo de la Biblia se identifica con el hombre sobrio y paciente que hace del trabajo y la industria un deber para con Dios. Sus éxitos en este campo serán considerados como prueba de la aquiescencia de Dios. Su actividad, cada vez más creciente, será vista como prueba de la elección divina. Las virtudes que se exigen a los nuevos cristianos, como la diligencia, la moderación, la sobriedad y el ahorro, son las virtudes propias de los hombres de negocios que engrandecerán las comunidades llevando este espíritu y sus intereses más allá de sus primeras fronteras. El mundo se santificaba así mediante el esfuerzo y el trabajo. Estos, si bien no son necesarios para obtener la salvación, puesto que ella es algo que se da gratuitamente al predestinado, son indispensables como una prueba de que la misma ha sido lograda. "El ideal de vida a que aspiraba el puritano - dice Angélica Mendoza- tenía más de vida recta que de vida buena y debía obtenerse en el arduo cumplimiento de una rectitud, completa y visible, como prueba de gozar de la bendición divina." 34

Apoyado en estas ideas el puritano de la Nueva Inglaterra hará de su sociedad una institución de carácter mesiánico. Su misión, hemos visto ya, es instituir el Reino de Dios en la Tierra, desalojando de ella al Mal. Es el pueblo elegido por Dios que viene a redimir al mundo, arrancándolo de las garras del mal. Concepto mesiánico que más tarde ha de justificar su expansión por las llanuras del Oeste y más allá de sus fronteras con los pueblos que habían colonizado el resto de América. En esta su expansión política y territorial se presentará como pueblo redentor: primero, para libertar a los indígenas de las garras del Demonio, o, al menos, para liberar sus improductivas tierras; después, para llevar la civilización a pueblos que se habían empeñado en permanecer al margen del progreso. "La teocracia -sigue diciendo Angélica Mendoza- se justificó a sí misma afirmando ser una 'democracia de elegidos' cuyo destino evidente era la instauración de Dios en las tierras vírgenes de América; tanto la doctrina calvinista del Estado sostenida por sus líderes, como la certidumbre personal de cada puritano de estar en posesión de la 'gracia' irresistible con sus corolarios acerca de la condición del hombre después de su pecado original, le dieron un contenido misionero y una seguridad confortable para justificar toda clase de empresas que la teocracia emprendiera y permitió a los colonizadores desarrollar una disciplina y una energía inusitada al sentirse instrumentos de las decisiones divinas." $3 \overline{5}$

De acuerdo con el punto de vista puritano, la democracia va a ser una organización social propia de pueblos elegidos, predestinados. Esta organización tendrá, así, un origen divino; Dios viene a ser el personal garante de la misma. Interpretación que va a marcar también las relaciones de una parte de las fuerzas vivas de los Estados Unidos, acaso la más importante por activa, con los pueblos que se encuentren en sus fronteras materiales o dentro de su

34 Angélica Mendoza, op. cit., p. 28.

35 Op. cit., p. 17. 
influencia política y económica. Las dificultades de estos pueblos para lograr instituciones democráticas semejantes a las norteamericanas no van a ser vistas en función con la diversidad de su formación cultural, sino en función de una supuesta incapacidad proveniente de su alejamiento de las tareas propias de un pueblo predestinado. La Democracia se va a presentar como una organización social propia de un pueblo determinado, único capacitado para llevar a otros pueblos sus instituciones si previamente aceptan el "pacto político" que tiene sus antecedentes en esa relación entre Dios y los hombres a los cuales ha concedido su gracia.

\section{Las relaciones entre las dos Américas}

Las relaciones de los colonos puritanos con otros colonos menos afortunados y con los indígenas van a estar determinadas por la concepción del mundo y de la vida que los mismos se han formado a través de sus ideas religiosas. Ya hemos visto cómo de acuerdo con estas ideas el eje de esta concepción lo da la acción, el trabajo por el trabajo. El puritano no concibe una actividad que no tenga una finalidad práctica que, a su vez, sirva para alcanzar otra en un cadena interminable. El ocio no tiene sentido para éste; todo lo contrario: si el ocio tiene algún sentido tiene que ser negativo; la pasividad es considerada como diabólica. Sus éxitos en el campo de la acción son vistos como una prueba de que lo hecho está bien visto por Dios.

La caridad, en el sentido católico, es rechazada: nadie puede ayudar a los otros. Aquí sólo cabe el "ayúdate que Dios te ayudará". Cada individuo es el único responsable de su felicidad en esta tierra y su salvación en la otra. El individualismo, en este campo, es absoluto, y parece basado en un "Sálvese quien pueda".

El puritanismo, dice Tawney, sacrificará la fraternidad en aras de la libertad. ${ }^{36}$ Partiendo de su propia suficiencia, el puritano limita su sentido de solidaridad humana. No acepta desigualdad que no tenga su origen en el carácter de los individuos. Todos los hombres son iguales; la desigualdad proviene del carácter natural de los mismos: unos prefieren el trabajo y la actividad, otros la holganza y la pasividad. Las circunstancias nada tienen que ver con la riqueza o la pobreza; el hombre está siempre por encima de las circunstancias. El puritano no ve en la pobreza de los que caen a su lado una desgracia digna de compasión y ayuda, sino la prueba de un fracaso moral que lejos de compadecerse debe ser condenado. Las riquezas, por otro lado, no tienen por qué ser objeto de sospecha sino de bendiciones. Estas no son sino expresión de lo que puede lograr un carácter enérgico, templado, que ha hecho del trabajo el eje de su actividad. La desgracia o la fortuna no son sino expresiones de la índole de los individuos. Dios premia o castiga al indi-

36 Op. cit. 
viduo en las obras que éste realiza de acuerdo con el comportamiento moral del mismo. El bueno obtendrá buenos frutos; el malo, malos. De aquí la hostilidad del puritano para con la pobreza y su negativa a ver en el pobre, como lo veía el Cristianismo primitivo, a un representante de Cristo en la tierra. La mendicidad fué prohibida y la vagancia perseguida, como expresiones malignas.

Frente a esta interpretación del trabajo como eje de la vida puritana, se alzaban en sus fronteras otros pueblos con otra concepción del mundo y de la vida distintas: los pueblos latinos. Al norte los franceses y al sur los hispanos. Pueblos, especialmente el hispano, que no hacían del trabajo por el trabajo una institución moral. Pueblos que ya llevaban la semilla de su actitud en su propia religión. Pueblos que no se preocupaban mucho por el dominio de la naturaleza, más allá de lo que reclamaban sus necesidades. Pueblos que aún aceptaban la tradición y basaban en ella sus diferencias sociales. Pueblos cuya organización social tenía sus raíces en autoritarismos de diversas especies. Pueblos, en fin, alejados de los signos que Dios hacía patentes en los pueblos que había elegido para su propia realización.

Estos pueblos, ineptos para cumplir la misión que Dios ha impuesto al hombre sobre la tierra, tenían que ser desalojados, como lo estaban siendo los indígenas, que tampoco cumplían con su misión de hombres. Francia y España cederían, ante diversos argumentos, sus territorios en Norteamérica. Pero al sur quedaban otras tierras y otros hombres cuya índole mostraba también signos negativos. Pueblos a los cuales, tanto la protestante Inglaterra como la puritana Norteamérica, ofrecerán diversos medios para que se independicen, tanto política como mentalmente, de la católica España y de los hábitos y costumbres que la misma les había impuesto. Les ofrecieron los instrumentos que hiciesen posible la manifestación de la misma índole de los pueblos que ya habían creado la forma democrática de organización social. Esa Democracia perseguida por los pueblos iberos al independizarse, políticamente, de la Metrópoli.

Los fracasos, las múltiples dificultades con que tropezaron los pueblos iberoamericanos para realizar esta democracia, unidos a la índole de su carácter, mostraron a los Estados Unidos, aunque ya dentro de otra interpretación, que se trataba de pueblos marginales, aún no maduros para la Democracia. La nueva interpretación, derivada de la primera, tendrá su apoyo en otra nueva forma de determinismo moderno: el progreso. Ya hemos visto al principio de este ensayo el sentido que para el hombre moderno tendrá esta idea. En ella la acción, el trabajo por el trabajo, sigue siendo el eje de la sociedad angloamericana. Dentro del progreso carecen de justificación los pueblos que no colaboraban con él inventando técnicas para dominar la naturaleza y transformarla. A pesar de todos sus esfuerzos, los iberoamericanos seguían siendo pueblos inhábiles para las industrias, torpes para las nuevas técnicas: pueblos 
sin sentido práctico de la vida, retóricos, conservadores, absolutistas. Sus gobiernos, a pesar de todas sus pretensiones, seguían siendo semejantes a los viejos gobiernos autoritarios legados por España y Portugal. La naturaleza, hecha para ser utilizada por el hombre, seguía guardando sus secretos en estas tierras. El hombre no se esforzaba en arrancar a la naturaleza otros frutos que los que la misma le ofrecía graciosamente. Los bosques guardaban aún ln riqueza de sus maderas preciosas y las selvas tropicales sus exquisitos frutos. En las entrañas de la tierra estaban aún los preciosos metales, que tan necesarios eran para construir las nuevas maquinarias, y el oro negro que podría moverlas. La riqueza natural de Iberoamérica era tan patente como la incapacidad de sus pueblos para explotarla. ${ }^{37}$

Norteamérica, con sus éxitos, daba origen a una nueva doctrina de acuerdo con los nuevos tiempos en los que el motor de la historia era el progreso. Doctrina en la que volvía a presentarse la idea de su predestinación como pueblo: "El Destino Manifiesto". Con éste justificaría, una vez más, su expansión territorial sobre México en 1847 y su futura expansión económica y política sobre el resto de Iberoamérica. Doctrina que encontraba su apoyo en la supuesta incapacidad de estos pueblos para el progreso y en el obstáculo que para el mismo representaban al dejar sin transformar la naturaleza que les había tocado en suerte. Esta idea del "Destino Manifiesto" entrará en pugna, dentro de la conciencia del iberoamericano, con la admiración que el mismo sentía por el pueblo que había originado las grandes instituciones democráticas que él trataba de realizar en sus pueblos a pesar de las enormes dificultades con que tropezaba. En torno a estas dos expresiones de la nación norteamericana girarán, en adelante, las relaciones entre las dos Américas. La Norteamérica del "Destino Manifiesto" será objeto de condena y la encarnación de todos los egoísmos y materialismos que los iberoamericanos le han achacado; la Norteamérica de la "Democracia" será, por el contrario, el arquetipo aspirado $y$ anhelado por los iberoamericanos para sus pueblos. ${ }^{38}$

LEOPOLDO ZEA

37 Véase mi libro Dós etapas del pensamiento en Hispanoamérica, El Colegio de México, 1949.

38 Véase mi trabajo titulado "Norteamérica en la conciencia hispanoamericana", en La filosofía como compromiso. Tezontle, Fondo de Cultura Económica, México, 1953. 